SciDioc

\section{Assessment of Pain Management Post Mandibular Third Molar Extraction with Piroxicam: A Retro- spective Analysis Over 10 Months}

Research Article

Gokul Gunasekaran ${ }^{1}$, Pradeep D ${ }^{2 *}$, Sri Rengalakshmi ${ }^{3}$

${ }^{1}$ Saveetha Dental College and Hospital, Saveetha Institute of Medical and Technical Sciences, Saveetha University, Chennai 600077, Tamil Nadu, India. ${ }^{2}$ Associate Professor, Department of Oral \& Maxillofacial Surgery, Saveetha Dental College and Hospital, Saveetha Institute of Medical and Technical Sciences, Saveetha University, Chennai 600077, Tamil Nadu, India.

${ }^{3}$ Senior Lecturer, Department of Orthodontics, Saveetha Dental College and Hospital, Saveetha Institute of Medical and Technical Sciences, Saveetha University, Chennai 600077, Tamil Nadu, India.

Abstract

Surgical removal of impacted mandibular third molar is one of the most commonly performed procedures in oral and maxillofacial surgical practice. The role of postoperative medications for management of postoperative pain is important for comfortable and uneventful healing. To assess and compare the therapeutic effect of piroxicam and other NSAIDs on patients undergoing surgical removal of impacted mandibular third molar, the study was conducted among patients who reported to a dental college for surgical removal of mandibular third molar. The data was collected and tabulated in MS-Excel and was analysed using SPSS software. Patients experience less post-operative pain on administration of piroxicam in comparison to other analgesics which will help to improve the post-operative pain. Piroxicam was found to have a better analgesic action in comparison to other analgesics given and also help to increase the postoperative comfort and quality of life.

Keywords: Analgesics; Third Molar; Pain; Piroxicam; Impaction.

\section{Introduction}

The surgical removal of impacted third molars is one of the most common minor oral surgery procedures widely carried out in general practice and also occupies an appreciable amount of clinical time in many hospitals in oral and maxillofacial departments [23]. The decision to remove the third molar is often difficult because of the consequences of the surgical extraction. Patients complain of pain, swelling, and limitation of mouth opening [50]. Frequently, this pain is moderate and temporary. Pain from lower third molar extraction reaches its maximum intensity $2-4 \mathrm{~h}$ after the end of surgery, and, in most cases, patients require analgesic treatment. Besides pain, swelling and the limited articulation of the temporomandibular joint associated with inflammation, there are further who undergo surgical interventions in the oral cavity and treatment for pain, trismus and swelling after lower third molar surgery includes non-steroidal anti-inflammatory require anal- gesic treatment $[23,7,4]$. The role of preoperative and postoperative medications in reducing postoperative complications has been extensively evaluated. Nonsteroidal anti-inflammatory drugs (NSAIDs) inhibit the synthesis of prostaglandins and reduce the inflammatory reaction and nociceptive stimuli causing reduction in pain. Piroxicam, a NSAID with a long half-life and potent analgesic activity similar to that of indomethacin, [55] has been developed in a new sublingual formulation. It is easily administered and does not have any harmful effects in the oral cavity. Although the analgesic effect of piroxicam in several types of pain (e.g., postoperative pain, acute renal colic, [49] dysmenorrhea, osteoarthritis, [36] low back pain, headache, and migraine [27] has been investigated. Surgical trauma activates a biochemical cascade, with the synthesis or release of prostaglandins, bradykinin, substance$\mathrm{P}$, histamine, and other substances. They interact to produce plasma extravasation, leading to edema. They also excite and sensitize peripheral nerve endings, resulting in the clinical manifestation of hyperalgesia. These substances have several other effects on

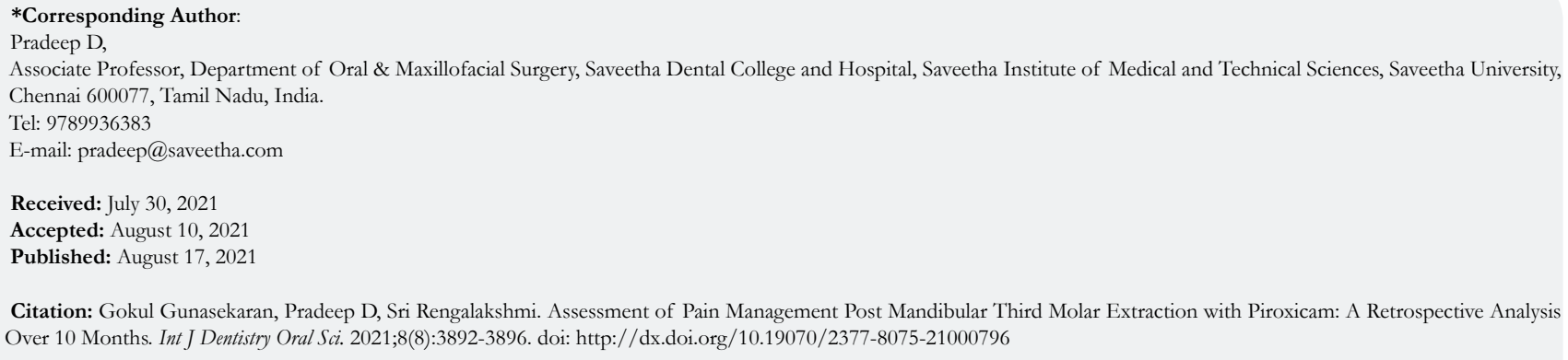

Copyright: Pradeep $\mathbf{D}^{\circ}$ 2021. This is an open-access article distributed under the terms of the Creative Commons Attribution License, which permits unrestricted use, distribution and reproduction in any medium, provided the original author and source are credited. 
peripheral nerve endings. They stimulate the release of neuropeptides such as calcitonin gene-related peptide (CGRP) from peripheral nerve endings, contributing to the synergistic effects of other biochemical cascades. These substances form a positive feedback loop that is thought to continually refuel the inflammatory process, maintaining the clinical signs of inflammation for days after the initial stimulus [8]. NSAIDs including piroxicam are not completely free of adverse effects. Some individuals exhibit allergic reactions to NSAIDs. Patients with an increased risk for hepatic failure, peptic ulcers, and gastrointestinal inflammation should avoid using NSAIDs, including piroxicam [24, 12]. Complications of extraction such as dry socket can be treated with ZOE paste [16]. In another study, Irrespective of the year of study, majority of the students showed a negative attitude toward HIV/AIDS patients and only a few among the interns showed a positive approach toward treating HIV patients [37]. This present study compares the efficacy of piroxicam versus other analgesics in surgical extraction of mandibular third molars and assessing the post-operative pain experience by the patients.

Previously our team has a rich experience in working on various research projects across multiple disciplines. (Jain, 2017 [14]); (Varghese, Ramesh and Veeraiyan, 2019 [51]); (Ashok and Ganapathy, 2019 [3]); (Padavala and Sukumaran, 2018 [29]); (Ke et al., 2019 [17]); (Ezhilarasan, 2018 [9]); (Krishnan et al., 2018 [18]); (Ezhilarasan, Sokal and Najimi, 2018 [9]); (Pandian, Krishnan and Kumar, 2018 [31]); (Ramamurthy and Mg, 2018 [39]); (Gupta, Ariga and Deogade, 2018 [13]); (Vikram et al., 2017 [54]); (Paramasivam, Vijayashree Priyadharsini and Raghunandhakumar, 2020 [32]); (Palati et al., 2020 [30]); (Samuel, Acharya and Rao, 2020 [44]) Now the growing trend in this area motivated us to pursue this project.

\section{Materials and Methods}

This retrospective study was conducted in the university setting. Data chosen for evaluations were patients who reported to a den- tal college for the removal of mandibular third molars. The details of the patients were obtained from analysis of 86,000 patients from June 2019 to March 2020 from patient dental records for the purpose of preservation and efficient analysis of the patient's details including intraoral and extra oral pictures and treatments being done, which is maintained in a confidential manner. These serve as records for the retrospective studies. The study was conducted after getting ethical approval from the Institutional Ethical Committee (Ethical approval number: SDC/SIHEC/2020/ DIASDATA/0619-0320). Cross verification was done with the help of patient dental records data. To minimize sampling bias all data were included. The inclusion criteria included patients who required removal of impacted mandibular third molars, prophylactic removal of mandibular third molars and patients with acute pericoronitis. The exclusion criteria included patients with drug allergies, medically compromised patients and patients who are pregnant or current lactation. Data was downloaded from the patient dental records and imported to Excel. Data which was not required were excluded. Excel tabulation was done and imported to SPSS and results were obtained in the form of graphs and tables. The advantages of the study included easy accessibility and availability of the required data and drawback was the available data was not location specific and belonged to different ethnicity. Independent variables that were included in the study - age, gender, tooth number (mandibular third molars), analgesic. The dependent variable included post-operative pain. The correlation and association between the variables were analysed and assessed using this test.

\section{Results \& Discussion}

A total number of 694 patients had undergone surgical extraction of mandibular third molars. Of these 153 patients were administered aceclofenac, 17 diclofenac, 141 paracetamol and 342 Piroxicam. Figure 1 shows better efficacy of analgesics in the younger age group. Figure 2 shows males to have a better analgesic effect compared to females. From Figure 3 we can conclude

Figure 1: This bar graph represents the association between age groups and the analgesic effect of drugs post mandibular third molar extraction-axis represents the age distribution and Y-axis represents the total number of patients who underwent mandibular third molar extraction(Blue: Painless, Green: Pain ). Chi-square test was done and association was found to be statistically Not significant. Pearson's Chi square value: $p$ value: $0.524(>0.05)$ Hence not statistically significant, proving age does not influence the analgesic effect of drugs post mandibular third molar extraction.

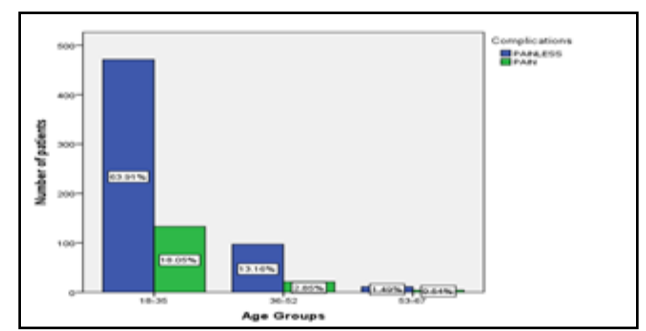

Figure 2: This bar graph represents the association between gender and the analgesic effect of drugs post mandibular third molar extraction. $\mathrm{X}$-axis represents the age distribution and Y-axis represents the total number of patients who underwent mandibular third molar extraction (Blue: Painless, Green: Pain). Chi-square test was done and association was found to be statistically significant. Pearson's Chi square value: $\mathrm{p}$ value: $0.418(>0.05)$ Hence not statistically significant, proving gender does not influences the analgesic effect of drugs post mandibular third molar extraction.

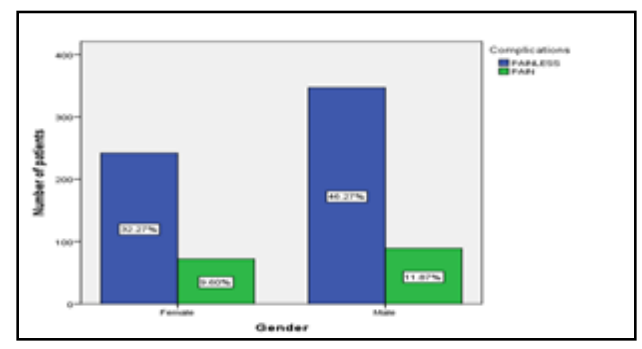


Figure 3: This bar graph represents the association between different analgesic drugs and the analgesic effect of the drugs post mandibular third molar extraction. $\mathrm{X}$-axis represents the analgesic drugs and $\mathrm{Y}$-axis represents the total number of patients who underwent mandibular third molar extraction (Blue: Painless, Green: Pain). Chi-square test was done and association was found to be statistically significant. Pearson's Chi square value: $p$ value: $0.000(<0.05)$ Hence, it is statistically significant, proving piroxicam has a better analgesic effect when compared to other drugs post mandibular third molar extraction.

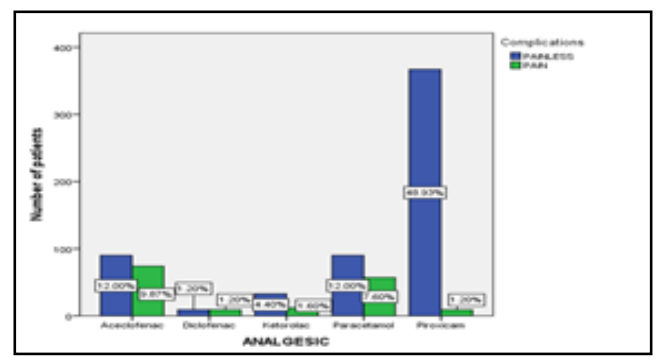

that piroxicam has a better efficiency to control pain post extraction, diclofenac and paracetamol have the least efficacy in pain control. Ketorolac and aceclofenac were found to have an intermediate efficiency in controlling pain. Piroxicam was found to be a better analgesic for surgical extraction comparatively. From Figure 1, Painless extractions were highest in the age group 1835 years $(63.91 \%)$ followed by $36-52$ years $(13.16 \%)$ and $53-67$ years $(1.49 \%)$. The extractions reported with pain were also highest in 18-35 years (18.05\%) followed by $36-52$ years $(2.85 \%)$ and $53-67$ years $(0.54 \%)$. Chi-square test was done and association was found to be statistically insignificant. Pearson's Chi square value: $p$ value: $0.524(>0.05)$. Hence not statistically significant. So age is not a factor for confirming the effectiveness of piroxicam. From Figure 2, Painless post-extraction periods were highest in the males (46.27\%) and females (32.27\%). The extractions reported with pain were also highest in males $(11.87 \%)$ and females (9.60\%). Chi-square test was done and association was found to be statistically significant .Pearson's Chi square value: $p$ value: $0.418(>0.05)$ Hence not statistically significant. So gender is not a factor for confirming the effectiveness of piroxicam. From Figure 3, Painless post-extraction periods were highest in the Piroxicam (48.93\%), Paracetamol (12\%) and Aceclofenac (12\%), Ketorolac $(4.40 \%)$ and Diclofenac $(1.20 \%)$. The extractions reported with pain were also highest in Aceclofenac (9.87\%), Paracetamol $(7.60 \%)$, Ketorolac(1.60\%) Piroxicam (1.20\%), and Diclofenac $(1.20 \%)$.Chi-square test was done and association was found to be statistically significant .Pearson's Chi square value: $p$ value: $0.000(<0.05)$. So, proving piroxicam has a better analgesic effect when compared to other drugs post mandibular third molar extraction.

The presence of pain during the postoperative period after third molar extraction is the chief indicator. In this study we can compare the efficacy of pain with the control group of drugs; Diclofenac, Aceclofenac, Paracetamol and Ketorolac among different age groups. Other studies deal with the swelling, trismus, pain post third molar extraction(Shruthi, no date). A Sunshine et al study on Piroxicam provided evidence for longer duration of analgesic action compared to codeine or aspirin [48]. In another study, ketorolac $10 \mathrm{mg}$ is more effective than Paracetamol 500mg as an analgesic after dental extractions [26]. Oropharyngeal airway volume has shown the highest post-surgical reduction though statistically insignificant $[6,2,14]$. The importance of training regarding biomedical waste management must be emphasized as the lack of proper and complete knowledge about it. [34] management impacts practices of appropriate waste disposal. [20]. A standard protocol regarding the training as well as preventive measures for surgical extractions should be formulated for the dental students and the knowledge acquired must be transferred into practice [45]. The etiology and pattern of maxillofacial injuries reflect the trauma patterns within the community and can thus provide a guide to help design programs toward prevention and treatment [28]. In another study, buccal fat pad graft proved to give better results as the interposition material as it has good patient acceptance, rapid epithelization, minimal donor site morbidity and minimal intra and postoperative complications [33, 21]. The ability to use Botox as an adjuvant and primary mode of the treatment for various maxillofacial disorders offers exciting treatment options for dentists and patients in the future [19, 15]. Surgical trauma activates a biochemical cascade, with the synthesis or release of prostaglandins, bradykinin, substance-P, histamine, and other substances. They interact to produce plasma extravasation, leading to edema. They also excite and sensitize peripheral nerve endings, resulting in the clinical manifestation of hyperalgesia. These substances have several other effects on peripheral nerve endings. They stimulate the release of neuropeptides such as calcitonin gene-related peptide (CGRP) from peripheral nerve endings, contributing to the synergistic effects of other biochemical cascades. These substances form a positive feedback loop that is thought to continually refuel the inflammatory process, maintaining the clinical signs of inflammation for days after the initial stimulus [8]. Acute pain serves an immediate sensory function, and the inflammatory process is important for normal tissue healing. However, pain and other inflammatory reactions may often overshoot their goal and cause unnecessary sequelae. The magnitude of postoperative pain depends on the degree of tissue damage and on the extent of operative trauma. Reducing pain and excessive inflammatory reactions is necessary not just for immediate reduction of postoperative morbidity, but also to provide prolonged benefits by preventing further worsening of pathologic states. In another study, there was a statistically significant reduction in pain on the postoperative days in the piroxicam group. No rescue treatment was required by any of the subjects in both the groups during the trial and sublingual piroxicam was effective in the management of postoperative pain following surgical removal of mandibular impacted third molar [25].

Our institution is passionate about high quality evidence based research and has excelled in various fields (Pc, Marimuthu and Devadoss, 2018 [35]; Ramesh et al., 2018 [40]; Vijayashree Priyadharsini, Smiline Girija and Paramasivam, 2018 [53]; Ezhilarasan, Apoorva and Ashok Vardhan, 2019 [10]; Ramadurai et al., 2019 [38]; Sridharan et al., 2019 [47]; Vijayashree Priyadharsini, 2019 [52]; Chandrasekar et al., 2020 [5]; Mathew et al., 2020 [22]; R et 
al., 2020 [42]; Samuel, 2021 [43] ). We hope this study adds to this rich legacy.

\section{Conclusion}

Within the limitations of the study, the efficacies of piroxicam among other NSAIDs was found to be significantly high and in different age groups and gender were found to be not very significant for comparison as a better analgesic when compared to other NSAIDs. In the future studies, larger sample size with multicentered and multiple ethnic groups should be involved to get better results.

\section{References}

[1]. Abhinav RP, Selvarasu K, Maheswari GU, Taltia AA. The Patterns and Etiology of Maxillofacial Trauma in South India. Ann Maxillofac Surg. 2019 Jan-Jun;9(1):114-117. Pubmed PMID: 31293938.

[2]. Sweta VR, Abhinav RP, Ramesh A. Role of Virtual Reality in Pain Perception of Patients Following the Administration of Local Anesthesia. Ann Maxillofac Surg. 2019 Jan-Jun;9(1):110-113. Pubmed PMID: 31293937.

[3]. Ashok V, Ganapathy D. A geometrical method to classify face forms. J Oral Biol Craniofac Res. 2019 Jul-Sep;9(3):232-235. Pubmed PMID: 31198677.

[4]. Benetello V, Sakamoto FC, Giglio FP, Sakai VT, Calvo AM, Modena KC, Colombini BL, Dionísio TJ, Lauris JR, Faria FA, Santos CF. The selective and non-selective cyclooxygenase inhibitors valdecoxib and piroxicam induce the same postoperative analgesia and control of trismus and swelling after lower third molar removal. Braz J Med Biol Res. 2007 Aug;40(8):113340. Pubmed PMID: 17665051.

[5]. Chandrasekar R, Chandrasekhar S, Sundari KKS, Ravi P. Development and validation of a formula for objective assessment of cervical vertebral bone age. Prog Orthod. 2020 Oct 12;21(1):38. Pubmed PMID: 33043408.

[6]. Christabel A, Anantanarayanan P, Subash P, Soh CL, Ramanathan M, Muthusekhar MR, Narayanan V. Comparison of pterygomaxillary dysjunction with tuberosity separation in isolated Le Fort I osteotomies: a prospective, multi-centre, triple-blind, randomized controlled trial. Int J Oral Maxillofac Surg. 2016 Feb;45(2):180-5. Pubmed PMID: 26338075.

[7]. Colombini BL, Modena KC, Calvo AM, Sakai VT, Giglio FP, Dionísio TJ, Trindade AS Jr, Lauris JR, Santos CF. Articaine and mepivacaine efficacy in postoperative analgesia for lower third molar removal: a double-blind, randomized, crossover study. Oral Surg Oral Med Oral Pathol Oral Radiol Endod. 2006 Aug;102(2):169-74. Pubmed PMID: 16876058.

[8]. Dionne RA, Snyder J, Hargreaves KM. Analgesic efficacy of flurbiprofen in comparison with acetaminophen, acetaminophen plus codeine, and placebo after impacted third molar removal. J Oral Maxillofac Surg. 1994 Sep;52(9):919-24; discussion 25-6. Pubmed PMID: 8064454.

[9]. Ezhilarasan D. Oxidative stress is bane in chronic liver diseases: Clinical and experimental perspective. Arab J Gastroenterol. 2018 Jun;19(2):56-64. Pubmed PMID: 29853428.

[10]. Ezhilarasan D, Apoorva VS, Ashok Vardhan N. Syzygium cumini extract induced reactive oxygen species-mediated apoptosis in human oral squamous carcinoma cells. J Oral Pathol Med. 2019 Feb;48(2):115-121. Pubmed PMID: 30451321.

[11]. Ezhilarasan D, Sokal E, Najimi M. Hepatic fibrosis: It is time to go with hepatic stellate cell-specific therapeutic targets. Hepatobiliary Pancreat Dis Int. 2018 Jun;17(3):192-197. Pubmed PMID: 29709350.

[12]. Faunce TA, Johnston K, Bambrick H. Trans-Tasman Therapeutic Products Authority: Potential AUSFTA Impacts on Safety and Cost-Effectiveness Regulation for Medicines and Medical Devices in New Zealand. Victoria U. Wellington L. Rev.. 2006;37:365.

[13]. Gupta P, Ariga P, Deogade SC. Effect of Monopoly-coating Agent on the Surface Roughness of a Tissue Conditioner Subjected to Cleansing and Disinfection: A Contact Profilometric In vitro Study. Contemp Clin Dent. 2018 Jun;9(Suppl 1):S122-S126. Pubmed PMID: 29962776.

[14]. Jain AR. Prevalence of partial edentulousness and treatment needs in rural population of South India. World J Dent. 2017 Jun;8(3):213-7.

[15]. Vijayakumar Jain S, Muthusekhar MR, Baig MF, Senthilnathan P, Loganathan S, Abdul Wahab PU, Madhulakshmi M, Vohra Y. Evaluation of ThreeDimensional Changes in Pharyngeal Airway Following Isolated Lefort One Osteotomy for the Correction of Vertical Maxillary Excess: A Prospective Study. J Maxillofac Oral Surg. 2019 Mar;18(1):139-146. Pubmed PMID: 30728705

[16]. Jesudasan JS, Wahab PU, Sekhar MR. Effectiveness of $0.2 \%$ chlorhexidine gel and a eugenol-based paste on postoperative alveolar osteitis in patients having third molars extracted: a randomised controlled clinical trial. Br J Oral Maxillofac Surg. 2015 Nov;53(9):826-30. Pubmed PMID: 26188932.

[17]. Ke Y, Al Aboody MS, Alturaiki W, Alsagaby SA, Alfaiz FA, Veeraraghavan VP, Mickymaray S. Photosynthesized gold nanoparticles from Catharanthus roseus induces caspase-mediated apoptosis in cervical cancer cells (HeLa). Artif Cells Nanomed Biotechnol. 2019 Dec;47(1):1938-1946. Pubmed PMID: 31099261.

[18]. Krishnan RP, Ramani P, Sherlin HJ, Sukumaran G, Ramasubramanian A, Jayaraj G, Don KR, Santhanam A. Surgical Specimen Handover from Operation Theater to Laboratory: A Survey. Ann Maxillofac Surg. 2018 JulDec;8(2):234-238. Pubmed PMID: 30693238.

[19]. Kumar, S. (2017) 'THE EMERGING ROLE OF BOTULINUM TOXIN IN THE TREATMENT OF OROFACIAL DISORDERS: LITERATURE UPDATE', Asian Journal of Pharmaceutical and Clinical Research, p. 21.

[20]. Kumar S, Rahman R. Knowledge, awareness, and practices regarding biomedical waste management among undergraduate dental students. Asian Journal of Pharmaceutical and Clinical Research. 2017;10(8):341.

[21]. Marimuthu M, Andiappan M, Wahab A, Muthusekhar MR, Balakrishnan A, Shanmugam S. Canonical Wnt pathway gene expression and their clinical correlation in oral squamous cell carcinoma. Indian J Dent Res. 2018 MayJun;29(3):291-297. Pubmed PMID: 29900911.

[22]. Mathew MG, Samuel SR, Soni AJ, Roopa KB. Evaluation of adhesion of Streptococcus mutans, plaque accumulation on zirconia and stainless steel crowns, and surrounding gingival inflammation in primary molars: randomized controlled trial. Clin Oral Investig. 2020 Sep;24(9):3275-3280. Pubmed PMID: 31955271.

[23]. McGrath C, Comfort MB, Lo EC, Luo Y. Changes in life quality following third molar surgery--the immediate postoperative period. Br Dent J. 2003 Mar 8;194(5):265-8; discussion 261. Pubmed PMID: 12658303.

[24]. Meredith TJ, Vale JA. Non-narcotic analgesics. Problems of overdosage. Drugs. 1986;32 Suppl 4:177-205. Pubmed PMID: 3552583.

[25]. Mohammad S, Singh V, Wadhwani P, Tayade HP, Rathod OK. Sublingual piroxicam in the management of postoperative pain after surgical removal of impacted mandibular third molar. Indian J Dent Res. 2012 NovDec;23(6):839-40. Pubmed PMID: 23649080.

[26]. MP SK. Relationship between dental anxiety and pain experience during dental extractions. Asian Journal of Pharmaceutical and Clinical Research. 2017 Mar 1:458-61.

[27]. Nappi G, Micieli G, Tassorelli C, Viotti E, Altavilla T. Effectiveness of a piroxicam fast dissolving formulation sublingually administered in the symptomatic treatment of migraine without aura. Headache. 1993 Jun;33(6):296300. Pubmed PMID: 8349471.

[28]. Packiri S, Gurunathan D, Selvarasu K. Management of Paediatric Oral Ranula: A Systematic Review. J Clin Diagn Res. 2017 Sep;11(9):ZE06-ZE09. Pubmed PMID: 29207849.

[29]. Padavala S, Sukumaran G. Molar Incisor Hypomineralization and Its Prevalence. Contemp Clin Dent. 2018 Sep;9(Suppl 2):S246-S250. Pubmed PMID: 30294152.

[30]. Palati S, Ramani P, Shrelin HJ, Sukumaran G, Ramasubramanian A, Don KR, Jayaraj G, Santhanam A. Knowledge, Attitude and practice survey on the perspective of oral lesions and dental health in geriatric patients residing in old age homes. Indian J Dent Res. 2020 Jan-Feb;31(1):22-25. Pubmed PMID: 32246676.

[31]. Pandian KS, Krishnan S, Kumar SA. Angular photogrammetric analysis of the soft-tissue facial profile of Indian adults. Indian J Dent Res. $2018 \mathrm{Mar}-$ Apr;29(2):137-143. Pubmed PMID: 29652003.

[32]. Paramasivam A, Vijayashree Priyadharsini J, Raghunandhakumar S. N6adenosine methylation $(\mathrm{m} 6 \mathrm{~A})$ : a promising new molecular target in hypertension and cardiovascular diseases. Hypertens Res. 2020 Feb;43(2):153154. Pubmed PMID: 31578458.

[33]. Patil SB, Durairaj D, Suresh Kumar G, Karthikeyan D, Pradeep D. Comparison of Extended Nasolabial Flap Versus Buccal Fat Pad Graft in the Surgical Management of Oral Submucous Fibrosis: A Prospective Pilot Study. J Maxillofac Oral Surg. 2017 Sep;16(3):312-321. Pubmed PMID: 28717289.

[34]. Patturaja K, Pradeep D. Awareness of Basic Dental Procedure among General Population. Res J Pharm Technol. 2016;9(9):1349-51.

[35]. J PC, Marimuthu T, C K, Devadoss P, Kumar SM. Prevalence and measurement of anterior loop of the mandibular canal using CBCT: A cross sectional study. Clin Implant Dent Relat Res. 2018 Aug;20(4):531-534. Pubmed PMID: 29624863.

[36]. Ragni N, Ciccarelli A. La terapia della dismenorrea primaria con piroxicam sublinguale [Primary dysmenorrhea treated with sublingual piroxicam]. Minerva Ginecol. 1993 Jul-Aug;45(7-8):365-75. Italian. Pubmed PMID: 8414145 .

[37]. Rahman R. Knowledge, Attitude And Awareness Of Dental Undergraduate Students Regarding Hiv/Aids Patients. Asian Journal of Pharmaceutical and 
Clinical Research. 2017 May 1:175-80.

[38]. Ramadurai N, Gurunathan D, Samuel AV, Subramanian E, Rodrigues SJL. Effectiveness of $2 \%$ Articaine as an anesthetic agent in children: randomized controlled trial. Clin Oral Investig. 2019 Sep;23(9):3543-3550. Pubmed PMID: 30552590.

[39]. Ramamurthy JA, Mg V. Comparison of effect of Hiora mouthwash versus Chlorhexidine mouthwash in gingivitis patients: A clinical trial. Asian J Pharm Clin Res. 2018 Jul 7;11(7):84-8.

[40]. Ramesh A, Varghese S, Jayakumar ND, Malaiappan S. Comparative estimation of sulfiredoxin levels between chronic periodontitis and healthy patients - A case-control study. J Periodontol. 2018 Oct;89(10):1241-1248. Pubmed PMID: 30044495.

[41]. Rao TD, Kumar MP. Analgesic efficacy of paracetamol vs ketorolac after dental extractions. Res J Pharm Technol. 2018;11(8):3375-9.

[42]. R H, Ramani P, Ramanathan A, R JM, S G, Ramasubramanian A, K M. CYP2 C9 polymorphism among patients with oral squamous cell carcinoma and its role in altering the metabolism of benzo[a]pyrene. Oral Surg Oral Med Oral Pathol Oral Radiol. 2020 Sep;130(3):306-312. Pubmed PMID: 32773350.

[43]. Samuel SR. Can 5-year-olds sensibly self-report the impact of developmental enamel defects on their quality of life? Int J Paediatr Dent. 2021 Mar;31(2):285-286. Pubmed PMID: 32416620.

[44]. Samuel SR, Acharya S, Rao JC. School Interventions-based Prevention of Early-Childhood Caries among 3-5-year-old children from very low socioeconomic status: Two-year randomized trial. J Public Health Dent. 2020 Jan;80(1):51-60. Pubmed PMID: 31710096.

[45]. Sneha S. Knowledge and awareness regarding antibiotic prophylaxis for infective endocarditis among undergraduate dental students. Asian Journal of Pharmaceutical and Clinical Research. 2016 Oct 1:154-9.

[46]. Shruthi D. 'Analgesics in Post-Operative Pain Control after Removal of Third Molar Impaction'. Available at:

[47]. Sridharan G, Ramani P, Patankar S, Vijayaraghavan R. Evaluation of salivary metabolomics in oral leukoplakia and oral squamous cell carcinoma. J Oral Pathol Med. 2019 Apr;48(4):299-306. Pubmed PMID: 30714209.

[48]. Sunshine A, Roure C, Colon A, Olson NZ, Gonzalez L, Siegel C, Laska E. Analgesic efficacy of piroxicam in the treatment of postoperative pain. Am J Med. 1988 May 20;84(5A):16-22. Pubmed PMID: 3287907.

[49]. Supervía A, Pedro-Botet J, Nogués X, Echarte JL, Mínguez S, Iglesias ML, Gelabert A. Piroxicam fast-dissolving dosage form vs diclofenac sodium in the treatment of acute renal colic: a double-blind controlled trial. Br J Urol. 1998 Jan;81(1):27-30. Pubmed PMID: 9467472.

[50]. UStün Y, Erdogan O, Esen E, Karsli ED. Comparison of the effects of 2 doses of methylprednisolone on pain, swelling, and trismus after third molar surgery. Oral Surg Oral Med Oral Pathol Oral Radiol Endod. 2003 Nov;96(5):535-9. Pubmed PMID: 14600686.

[51]. Varghese SS, Ramesh A, Veeraiyan DN. Blended Module-Based Teaching in Biostatistics and Research Methodology: A Retrospective Study with Postgraduate Dental Students. J Dent Educ. 2019 Apr;83(4):445-450. Pubmed PMID: 30745352.

[52]. Vijayashree Priyadharsini J. In silico validation of the non-antibiotic drugs acetaminophen and ibuprofen as antibacterial agents against red complex pathogens. J Periodontol. 2019 Dec;90(12):1441-1448. doi: 10.1002/ JPER.18-0673. Epub 2019 Jul 12. PMID: 31257588.

[53]. Vijayashree Priyadharsini J, Smiline Girija AS, Paramasivam A. In silico analysis of virulence genes in an emerging dental pathogen A. baumannii and related species. Arch Oral Biol. 2018 Oct;94:93-98. Pubmed PMID: 30015217.

[54]. Vikram NR, Prabhakar R, Kumar SA, Karthikeyan MK, Saravanan R. Ball Headed Mini Implant. J Clin Diagn Res. 2017 Jan;11(1):ZL02-ZL03. Pubmed PMID: 28274084.

[55]. Ward A, Brogden RN, Heel RC, Speight TM, Avery GS. Etretinate. A review of its pharmacological properties and therapeutic efficacy in psoriasis and other skin disorders. Drugs. 1983 Jul;26(1):9-43. Pubmed PMID: 6224672. 